\title{
THE PLACE OF THE UNDOCUMENTED WORKER IN THE UNITED STATES LEGAL SYSTEM AFTER HOFFMAN PLASTIC COMPOUNDS: AN ASSESSMENT AND COMPARISON WITH ARGENTINA'S LEGAL SYSTEM
}

\author{
María Pabón López"
}

\section{INTRODUCTION}

The undocumented worker's place in the U.S. legal system has been described as "deeply ambivalent." A leading immigration scholar coined this intriguing description more than fifteen years ago, shortly after the passage of the statute that outlawed the hiring of undocumented workers in the United States: the Immigration Reform and Control Act (IRCA). ${ }^{2}$ This deep ambivalence reveals a pragmatic measure of tolerance for these workers, who occupy a key place in the U.S. economy ${ }^{3}$-particularly in the low skill, low

* Assistant Professor of Law and Co-Director, Latin American Law Program, Indiana University School of Law-Indianapolis. J.D., University of Pennsylvania Law School; B.A., Princeton University. I thank Associate Dean Alfreda Robinson for entrusting me with the organization of the "Immigration in Modern America" panel at the Second National People of Color Legal Scholarship Conference, held in October 2004 at the George Washington University School of Law. It was in this panel that I presented this article. An earlier version of this article was presented at the Rivers of Law: The Confluence of Life, Work and Justice: Law and Society Association Annual Meeting 2003. I thank my colleagues Robin Kundis Craig and Karen Bravo for their comments on earlier drafts of this paper. I appreciate the work of Cynthia Carrasco, Indiana University School of Law, Indianapolis, Class of 2006, who provided excellent research assistance. I also appreciate the invaluable research support of Dragomir Cosanici, Head of Reference, Indiana University School of Law, Indianapolis. Finally, I am grateful for the assistance of Universidad Nacional de La Plata, Argentina Professors Rita Gajate, Sergio Palacios and Juan Amestoy as well that of Christian Gallo, Indiana University School of Law, Indianapolis, L.L. M. Class of 2005, who all gave of their time and energy to help me locate Argentine law sources. A summer research grant from Indiana University School of Law - Indianapolis funded the research for this article.

1. Linda Bosniak, Exclusion and Membership: The Dual Identity of the Undocumented Worker under United States Law, 1988 WIS. L. REv. 955, 1023 (1988).

2. See 8 U.S.C. \$ 1324a (1994) (making unlawful the employment of undocumented workers). IRCA also contained a provision for sanctioning employers who hired undocumented workers. Id.

3. Studies show that immigrant workers may add up to an estimated $\$ 10$ billion to the economy each year. See Overall U.S. Economy Gains from Immigration, But It's Costly to Some States and Localities, NAT'L ACAD. PRESS (May 17, 1997) (citing findings of a U.S. Commission on Immigration Reform study performed by the National Academy of Sciences, as stated by Rand Corp. economist James R. Smith, Commission Chair) (on file with author). The Urban Institute has estimated that undocumented workers have contributed $\$ 2.7$ billion to Social Security and another $\$ 168$ million to unemployment insurance taxes in the country. See THE VALUE OF UNDOCUMENTED WORKERS, AM. IMMIGRATION LAW FOUND. (April 2002) (on file with 
wage labor force sector ${ }^{4}$ - while at the same time underscoring their status as outsiders in the polity, based on their undocumented status. This state of deep ambivalence also reveals the coexistence of opposing attitudes or conflicting thoughts toward the undocumented workers, who have a dual nature in U.S. society, outsiders by nationality and lack of legal status and insiders because the U.S. economy needs their work. Despite this deep ambivalence, the years following the passage of IRCA saw a record growth in the numbers of undocumented workers in the country, in response to the rising needs of the U.S. workforce. ${ }^{5}$ However, there has been no concomitant growth in IRCAauthorized sanctions imposed upon employers for whom the undocumented workers labor. ${ }^{6}$ As such, the deep ambivalence toward the undocumented worker has continued in the face of the lack of effective deterrents to the hiring of undocumented workers.

In the last three years, the seminal U.S. Supreme Court's decision in Hoffman Plastic Compounds, Inc. v. NLRB ${ }^{7}$ has rekindled the debate regarding the status of undocumented workers in the United States. In Hoffman, the Court denied an undocumented worker backpay, which the NLRB had awarded as a remedy to an unfair labor practice, finding that the award contradicted the policies of IRCA. ${ }^{8}$ The Hoffman decision has had an indelible effect upon legal norms in the United States regarding the rights of undocumented workers,

author), available at http://www.ailf.org/ipc/policy_reports_2002_value.asp. For a recent study of the economic impact of undocumented workers in a particular locality, see CHIRAG MEHTA ET AL., CHICAGO'S UNDOCUMENTED IMMIGRANTS: AN ANAL YSIS OF WAGES, WORKING CONDITIONS AND ECONOMIC CONTRIBUTIONS, UNIVERSITY OF ILLINOIS CHICAGO 34 (2002) (discussing contributions of undocumented workers in the Chicago metropolitan area in the amount of 5.45 billion dollars annual spending, generating an additional 31908 jobs yearly to the local economy), available at http://www.uic.edu/cuppa/uicued/Publications/RECENT/undoc_full.pdf.

4. Undocumented workers are overrepresented in certain low skill, low wage labor force sectors. For example, undocumented workers account for about ten percent of all restaurant workers, and nearly twenty-five percent of all private household workers in the United States. See B. LINDSAY LOWELl \& RiCHARD FRY, PEW HISPANIC CENTER, ESTIMATING THE DisTRIBUTION OF UNDOCUMENTED WORKERS IN THE URBAN LABOR FORCE 4 (2002), available at http://pewhispanic.org/files/reports/6.1.pdf (on file with author).

5. As of October 1992, the Immigration and Naturalization Service (INS) estimated the number of undocumented population in the United States at 3.9 million. See Jeffrey Passel, Undocumented Immigration to the United States: Numbers, Trends, and Characteristics, in ILlEGAL IMMIGRATION IN AMERICA: A REFERENCE HANDBOOK 37 (David W. Haynes \& Karen E. Roseumblum, eds. 1999).

6. In fact, the available data shows that for the years 2003 and 2004 , only fifteen employers nationwide were fined for hiring undocumented workers. See DEPARTMENT OF

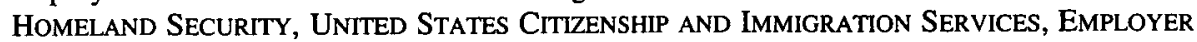
SANCTIONS FINAL ORDER, available at http://uscis.gov/graphics/aboutus/foia/ereadrm/ esdefin4.htm (last visited March 21, 2005). The amount of the fines imposed during these years has ranged from a low of $\$ 2200$ to a high of $\$ 59,356.60$. Id. In another telling statistic, nationwide media attention has focused on the fact that in 2002, the former Immigration and Naturalization Service issued orders levying fines on only thirteen employers for hiring undocumented workers. Donald L. Bartlett \& James B. Steele, Who Left the Door Open?, TIME, Sept.20, 2004, at 51.

7. 535 U.S. 137 (2002).

8. Id. at 149 . 
particularly at a time when the nation is coming to terms with the sheer number of undocumented workers ${ }^{9}$ within its borders.

The undocumented worker faces a conflict between labor law and immigration law: whether the undocumented worker's unauthorized immigration status should be given priority over the illegality of the employer who violates labor law by hiring undocumented workers. Thus, one must ask whether the place of the undocumented worker in the U.S. legal system is still deeply ambivalent after Hoffman, or has that ambivalent state deteriorated as a result of the decision.

This article analyzes the place of the undocumented worker in the U.S. legal system after Hoffman and argues that the attitude of the polity has moved beyond deep ambivalence to a hostile inconsistency, as evidenced by the conflicting treatment of the claims of undocumented workers by the lower courts. This hostile inconsistency becomes even more obvious when compared to the treatment of undocumented workers in Argentina, another country with a sizable immigrant population. In contrast to the almost insurmountable barriers to legal immigration in the U.S. for the majority of non-U.S. citizen workers, Argentina's legal system allows such workers easier access to Argentina's workforce. Furthermore, the country's legal regime treats undocumented workers in a markedly less hostile and inconsistent manner than does the U.S. legal system. Whereas sanctions against companies for employing undocumented workers are a part of the U.S. legal system, it is the case that they are not the primary focus of enforcement actions. In Argentina, the legal system does the opposite, focusing instead on the employer as a main locus of the legal sanction.

Part II of this paper analyzes the Hoffman opinion and explores how it has been interpreted in subsequent case law to illuminate the current norms that affect the lives of undocumented workers in the United States. Part III examines leading federal and state labor and employment laws and analyzes the predominant statutory regimes affecting undocumented workers. Part IV

9. Estimates show that there are approximately six million undocumented workers in the United States economy, representing about five percent of all United States workers. See

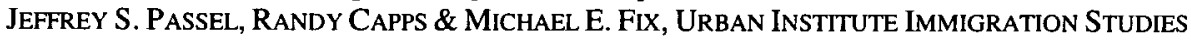
PROGRAM FACT SHEET, UNDOCUMENTED IMMIGRANTS: FACTS AND FIGURES (2004) (on file with author). Other estimates have shown a larger figure of undocumented workers, estimating the number at 7.8 million. See LowELL \& FRY, supra note 4 . The latest estimates of the total undocumented population in the United States are available from the Pew Hispanic Center and show that there are 10.3 million undocumented residents in the country, with undocumented Mexicans accounting for $57 \%$ of the undocumented population. See JefFrey S. PASSEL, PEw HISPANIC CENTER, ESTIMATES OF THE SIZE AND CHARACTERISTICS OF THE UNDOCUMENTED POPULATION 1 (2005), available at http://pewhispanic.org/files/reports/44.pdf (on file with author). The number of undocumented workers in the United States is understandably, hard to ascertain, as is, in general, subject of illegal immigration, which is "fraught with misinformation, and lack of information, complexity and paradox." David W. Haines \& Karen E. Rosenblum, Introduction: Problematic Labels, Volatile Issues, in ILLEGAL IMMIGRATION IN AMERICA, supra note 5 at 1 . 
analyzes the current status and treatment of undocumented workers in Argentina, including the legal norms of Mercado Común del Sur (MERCOSUR), ${ }^{10}$ South America's main regional economic integration regime. Part IV also provides a comparative analysis of the labor rights of undocumented workers in the United States and those of their counterparts in Argentina. Finally, this paper will conclude in Part V by canvassing proposed solutions to the hostile ambivalence towards undocumented workers in the U.S. legal system. These solutions will be assessed in an effort to better address the existence of undocumented workers, who are in this country to stay because of the economic situation and the cheap labor they provide. ${ }^{11}$

\section{HOFFMAN PLASTIC COMPOUNDS, INC. V. NLRB AND ITS AFTERMATH}

\section{A. Hoffman Plastic Compounds, Inc. v. NLRB - The Case}

The facts that give rise to Hoffman are as follows. José Castro and other employees of the Hoffman Plastic chemical compound production plant in Los Angeles took part in a campaign distributing authorization cards at their place of employment as part of a unionizing effort for the United Rubber, Cork, Linoleum, and Plastic Workers of America, an AFL-CIO affiliate. ${ }^{12}$ A month after this activity began, the company terminated the persons involved in the union organizing efforts, including Mr. Castro. ${ }^{13}$ Consequently, Mr. Castro and the other employees filed a complaint with the National Labor Relations Board (NLRB). Finding in favor of Mr. Castro and the other employees, the NLRB ordered that the company (1) cease and desist from further violations, (2) offer reinstatement and backpay to the employees; and (3) post a notice in the workplace regarding the order. ${ }^{14}$

During his testimony at an administrative compliance hearing held to determine the amount of backpay owed, $\mathrm{Mr}$. Castro revealed information about his unauthorized entry into the United States, lack of employment authorization, and the use of fraudulent documents to obtain employment. ${ }^{15}$ Taking into account this testimony, the Administrative Law Judge (ALJ) denied

10. MERCOSUR was created by the Treaty of Asuncion Establishing a Common Market among Argentina, Brazil, Paraguay, Uruguay. See Argentina-Brazil-Paraguay-Uruguay: Treaty Establishing a Common Market, Mar. 26, 1991, 30 I.L.M. 1041 (entered into force Dec. 31, 1994).

11. See Kevin Johnson, An Essay on Immigration, Citizenship, and U.S./Mexico Relations: The Tale of Two Treaties, 5 S.w. J. L. \& TRADE AM. 121, 141 (1998) (noting that business interests in the United States "treasure the cheap labor provided by the Mexican people"); see generally Christopher David Ruiz Cameron, The Labyrinth of Solidarity: Why the Future of the American Labor Movement Depends on Latino Workers, 53 U. MIAMI L. REV. 1089,1098 (1999) (discussing the essential nature of the Latino worker to the U.S. economy).

12. Hoffman Plastic Compounds, Inc., 535 U.S. at 140.

13. Id.

14. Id.

15. Id. at 141 . 
any backpay to Mr. Castro. Mr. Castro then appealed, and the NLRB reversed the ALJ's decision, ordering backpay for a period of three-and-a-half years, which it calculated from the day of discharge to the date that the company learned of Mr. Castro's undocumented status. ${ }^{16}$ The company appealed to the U.S. Supreme Court after the Court of Appeals for the District of Columbia Circuit had enforced the NLRB's backpay order. ${ }^{17}$

The Supreme Court granted certiorari in the case and reversed the D.C. Circuit. In a five to four decision, the Court held that Congress's federal immigration policy, as expressed in IRCA, prohibited the NLRB remedy of backpay for an undocumented worker who had never had legal authorization to obtain employment in the United States. ${ }^{18}$ The Court's decision resolved a circuit split: the Second and Ninth Circuit Courts of Appeal had allowed backpay awards to undocumented workers under the National Labor Relations Act (NLRA), whereas the Seventh Circuit Court of Appeals held exactly the opposite, denying backpay to the undocumented worker. ${ }^{19}$ The Court began its analysis by reviewing its pre-IRCA precedent, as set forth in Sure-Tan, Inc. $v$. $N L R B .{ }^{20}$ In Sure-Tan, the Court decided that an employer had engaged in an unfair labor practice by reporting to the Immigration and Naturalization Service (INS) certain undocumented workers in its workforce who had participated in union activities. $^{21}$

The Court based its holding on NLRA precedent holding that an employer constructively discharges an employee when, with the purpose of discouraging union activity, the company purposefully creates working conditions so intolerable that the employee is left with no choice but to resign. ${ }^{22}$ With regard to a remedy for the unfair labor practice, the Court conditioned backpay for the workers who had already been deported by requiring their legal reentry into the country and that they be legally entitled to be present and employed in the United States. ${ }^{23}$ In fashioning this remedy, the Court in SureTan balanced the policy regarding protection against unfair labor practices of the NLRA against the policy of the Immigration and Naturalization Act (INA) aimed at deterring undocumented immigration. ${ }^{24}$ Foreshadowing Hoffman, the Supreme Court in Sure-Tan afforded a limited remedy to undocumented workers by having the NLRA policy yield to the INA policy.

The Hoffman Court then turned its analysis to the IRCA's comprehensive scheme prohibiting the employment of undocumented workers and the penalties

16. Id. at 142. The amount of backpay was calculated at $\$ 66,951$. Id.

17. Hoffman Plastic Compounds, Inc. v. NLRB, 237 F.3d 639 (D.C. Cir. 2001).

18. Hoffman Plastic Compounds, Inc., 535 U.S. at 149.

19. Id. at $142 \mathrm{n} .2$. The NLRA is codified at 29 U.S.C. $\$ 151$ et. seq. (2000).

20. Sure-Tan, Inc. v. NLRB, 467 U.S. 883, 902-3 (1984).

21. Id. at 894 .

22. Id.

23. Id. at 902-3.

24. Id. at $912-3$. 
to both employers and employees for violations of the scheme. ${ }^{25}$ The Court found that Congress could not have meant for the NLRB to award backpay to an undocumented worker, who would otherwise be criminally liable for presenting false documents to obtain employment and who could not mitigate damages by obtaining other employment. ${ }^{26}$ The Court then resolved the controversy over which policy prevails when labor policy and immigration policy are at odds in the area of backpay remedies: immigration policy as expressed in the IRCA's prohibition against the hiring of undocumented workers carried the day. Continuing the trend started in Sure-Tan, the Court chose to place labor policy over immigration policy, even in the face of one illegality under immigration law, committed by the undocumented worker in obtaining unauthorized employment as compared to the double illegality of the employer in (1) the hiring of the undocumented worker and (2) the violation of labor law.

However, as clearly stated in the Hoffman opinion, the other NLRAimposed remedies, such as cease-and-desist orders and posting a notice to employees of their rights, with contempt enforcement, continue to apply to undocumented workers. ${ }^{27}$ The Court also distinguished its Hoffman opinion from its own precedent regarding the awarding of backpay to workers who had engaged in criminal acts, by noting that it has never deferred to the NLRB's remedial preferences when they "potentially trench upon federal statutes and policies unrelated to the NLRA."28 Furthermore, the Court rejected as a "slender reed"29 a House committee report, which the dissent cited and which stated that the IRCA "does not 'undermine or diminish in any way labor protections in existing law, or . . . limit the powers of federal or state labor relation boards ... to remedy unfair practices committed against undocumented employees." "30 Finally, the Court indicated that if relief is to be had, then it must be "addressed by Congressional action," not the courts. ${ }^{31}$

The dissent authored by Justice Breyer and joined by Justices Souter, Stevens, and Ginsburg first reviewed how all of the relevant agencies, including the Department of Justice, which was then in charge of overseeing INS's activities, had informed the Court that an award of backpay to an undocumented worker would not affect immigration policy. ${ }^{32}$ Then the dissenters warned that eliminating backpay as a deterrent in the NLRB's "remedial arsenal" left it with fewer "weapons" and only "future-oriented" remedies such as cease-and-desist orders. ${ }^{33}$ In the dissenters' view, this action

25. Hoffman Plastic Compounds, Inc., 535 U.S. at 148.

26. Id. at $149,151$.

27. Id. at 152 .

28. Id. at 144 .

29. Id. at $150 \mathrm{n} .4$.

30. Id. at 157 (Breyer, J., dissenting) (citing H.R. No. 99-682 pt. 1 at 58 (1986)).

31. Id at 152 (citing Sure-Tan, Inc, 467 U.S. at 904).

32. Id. at 153 (Breyer, J., dissenting).

33. $I d$. 
produced a counter effect to NLRA's policy, allowing employers to violate labor laws "at least once with impunity." 34

The dissent further stressed the effect of the majority opinion with respect to immigration policy, arguing that the unwarranted removal of a "critically important remedial power" from the NLRB gave employers a greater incentive to employ undocumented workers. ${ }^{35}$ Upon considering how the majority misapplied its own precedent, such as in Sure-Tan, the dissent concluded by stating that the NLRB's conclusion to award the backpay was reasonable, and the majority should have respected it. ${ }^{36}$ Furthermore, Justice Breyer asserted that the majority should not have substituted its own independent view of the matter over that of the NLRB. ${ }^{37}$ In the three years following Hoffman, much litigation has ensued with regard to its applicability to various other federal and state labor and employment law.

\section{B. Cases in the Three Years Following Hoffman: Mixed Results}

\section{Federal cases}

Following Hoffman, employers have argued that a myriad of federal laws do not apply to undocumented workers and that such workers are not entitled to the various comprehensive workforce protections afforded by U.S. law to its citizen or lawfully admitted workers. ${ }^{38}$ These arguments have met with mixed success. For example, in Zeng Liu v. Donna Karan International Inc., ${ }^{39}$ the employer, fashion designer Donna Karan's company, sought to discover plaintiff employees' immigration status in an unpaid wages Fair Labor Standards Act (FLSA) case. Karan argued that under Hoffman, if undocumented, the plaintiffs would be unable to collect the unpaid wages. ${ }^{40}$ The court disagreed and did not allow discovery, finding that the plaintiffs' immigration status was not relevant to its decision regarding unpaid wages, because Hoffman only concerned backpay as a remedy for a violation of the NLRA for work not performed, ${ }^{41}$ rather than backpay for work performed in the unpaid wages situation at hand.

34. Id.

35. Id. at 155 .

36. Id. at 160 .

37. Id. at 161.

38. See, e.g., Martinez v. Mecca Farms, Inc., 213 F.R.D. 601 (S.D. Fla. 2002) (employer opposed class certification in wage and damages claim, stating that following Hoffman,the Migrant and Seasonal Agricultural Worker Protection Act did not apply to undocumented workers); Flores v. Nissen, 213 F. Supp. 2d 871, 823 n.4 (N.D. Ill. 2002) (Defendant employee argued that Hoffman should bar plaintiff, undocumented fellow employee, from recovering backpay as part of damages suffered in car accident).

39. Zeng Liu v. Donna Karan Int'l Inc., 207 F. Supp. 2d 191, 192 (S.D.N.Y. 2002). The FLSA is codified at 29 U.S.C. $\$ 201$ et. seq. (2000).

40. Id.

41. Id. There are several other reported cases in which lower courts have denied 
In another FLSA case, Singh v. Jutla, ${ }^{42}$ the court denied an employer's motion to dismiss wherein the employer argued that the court read Hoffman broadly to prohibit undocumented workers from obtaining labor law remedies other than backpay. In this case, the employer had recruited the employee knowing of his undocumented status, never paid the employee for work performed for almost three years, and then, when the employee filed his FLSA claim for the unpaid wages, called the INS, resulting in the employee's detention. ${ }^{43}$ In fact, INS had detained Mr. Singh for fourteen months at the time of the writing of the opinion. ${ }^{44}$ The District Court for the Northern District of California refused to extend Hoffman to bar the remedies Mr. Singh sought for unpaid wages. ${ }^{45}$ The court noted that Hoffman did not preclude undocumented workers from seeking any form of relief. ${ }^{46}$ The court reasoned that, unlike in Hoffman, Mr. Singh sought to recover unpaid wages for work already performed, and as such, the remedies sought were not barred to him. ${ }^{47}$ The opinion did not reach the merits of Mr. Singh's case, that is, whether as an undocumented worker he would be able to recover damages and obtain injunctive relief under the FLSA against his employer for retaliating against him for filing an unpaid wage claim.

Yet another Hoffman discovery challenge took place in De La Rosa $v$. Northern Harvest Furniture, ${ }^{48}$ a Title VII ${ }^{49}$ action where the employer sought production of the employee's documents regarding his work authorization both at his time of employment and at the time of the litigation. ${ }^{50}$ In that case, the District Court for the Central District of Illinois found that " $[t]$ he only period for which immigration status might potentially be relevant" to the question of backpay under Title VII was the time after the employee was terminated and when the employer offered reinstatement. ${ }^{51}$ Because this time period was not one for which the defendant had requested employment authorization documents, the court denied the motion to compel discovery. ${ }^{52}$ The importance of the timing identified by the court in De La Rosa lies in the fact that a worker

employer's requests for discovery into employee's immigration status when the request involves unpaid wages under the FLSA. See Flores v. Albertsons, CV 01-00515 AHM, 2002 U.S. Dist LEXIS 6171 (C.D. Cal. Apr. 9, 2002); Flores v. Amigon, 233 F. Supp. 2d 462, 464 (E.D.N.Y. 2002); Cortez v. Medina's Landscaping, No. 00 C 6320, 2002 U.S. Dist. LEXIS 18831, at *2 (N.D. Ill. Sep. 30, 2002). In another case, Rodriguez v. The Texan, Inc., No. 01 C 1478, 2002 U.S. Dist. LEXIS 17379, at *7 (N.D. Ill. Sep. 13, 2002), the court granted a plaintiff's motion in limine to exclude any reference to his immigration status in an unpaid wages case under the FLSA.

42. Singh v. Jutla, 214 F. Supp. 2d. 1056, 1062 (N.D. Cal. 2002).

43. Id. at 1057 .

44. Id.

45. Id. at 1060 .

46. Id. at 1061 .

47. Id.

48. De La Rosa v. N. Harvest Furniture, 210 F.R.D. 237 (C.D. Ill. 2002).

49. Title VII of the Civil Rights Act of 1964,42 U.S.C. $\S 2000$ e (2004).

50. De La Rosa, 210 F.R.D. at 238-9.

51. Id. at 239.

52. Id. 
who is undocumented at the time of employment is not automatically disqualified from bringing an antidiscrimination claim under Title VII. Thus, there is no chilling effect to undocumented workers which would prevent them from bringing antidiscrimination actions under Title VII.

Notwithstanding its ruling, the De La Rosa court did note that in a Title VII case backpay is presumptively appropriate and "may only be denied for reasons which 'if applied generally, would not frustrate the central statutory purposes of eradicating discrimination . . . and making persons whole.",53 Furthermore, by contrasting its authority with that of the NLRB, the court hinted at what would happen if immigration law conflicted with antidiscrimination law, stating that it could not "conclude at this time that Hoffman is dispositive of the issues raised ...."54 Thus, the court also hinted at its possible resolution of the case-assuming discovery into the employees' employment authorization at the appropriate time period for Title VII backpay had taken place - a much different outcome than what happened to Mr. Castro in Hoffman. Mr. De La Rosa's undocumented status quite possibly would not have precluded his obtaining backpay as a remedy under the anti-discrimination statute.

The only federal appellate case to have considered Title VII in regard to undocumented workers following Hoffman has followed this view. The Ninth Circuit, in Rivera v. NIBCO, Inc., ${ }^{55}$ has stated in dicta that Hoffman is not broadly applicable and that it doubts it is germane to the Title VII context. ${ }^{56}$ The Ninth Circuit's view is based on the distinctions between the limited private enforcement allowed under the NLRA and the broad mandate under Title VII for individual plaintiffs to enforce the law by acting as private attorneys general. ${ }^{57}$ Thus, according to the Ninth Circuit, and contrary to the arguments of some asserting that the undocumented have no rights in this country, ${ }^{58}$ Hoffman's holding was limited to the NLRA.

There are other instances where the employee's legal action has survived a Hoffman challenge, but just barely. In López v. Superflex, Ltd., ${ }^{59}$ the

53. Id.

54. $I d$.

55. Rivera v. NIBCO, Inc., 364 F.3d 1057, 1067 (9th Cir. 2004), reh'g denied, 384 F.3d 822 (9th Cir. 2004), cert. denied, 73 U.S.L.W. 3415, 2005 WL 517010 (2005). The Supreme Court's recent denial of certiorari can be seen as reflecting a lack of intense dissatisfaction of the majority of the Justices with the decision below. See Peter Linzer, The Meaning of Certiorari Denials, 79 Colum. L. Rev. 1227, 1229 (1979).

56. Rivera, 364 F.3d at 1067.

57. Id.

58. See Christine Dana Smith, Give Us Your Tired, Your Poor: Hoffman and the Future of Immigrants' Workplace Rights, 72 U. CIN. L. REv. 363, 374 (2003) (narrating account of New York employer's attomey to an advocacy group stating: "I am sure you are aware of the ruling by the Supreme Court of the United States that illegal immigrants do not have the same rights as U.S. citizens.").

59. López v. Superflex, Ltd., No. 01 Civ. 10010 (NRB), 2002 U.S. Dist. LEXIS 15538 (S.D.N.Y. Aug. 21, 2002). 
employer sought to dismiss an Americans with Disabilities Act (ADA) claim $^{60}$ for punitive and compensatory damages, arguing that under Hoffman the employee needed to plead his lawful presence in the United States in his complaint. ${ }^{61}$ The District Court for the Southern District of New York denied the motion, finding no requirement that the employee plead that he was legally working in the United States, because the Supreme Court has rejected such heightened pleading unless mandated by the Federal Rules of Civil Procedure. ${ }^{62}$

The court in López did not rule on the issue of whether Hoffman applied to punitive and compensatory damages under the ADA. ${ }^{63}$ The court, however, did clearly emphasize that:

If Hoffman Plastics [sic] does deny undocumented workers the relief sought by plaintiff, then he would lack standing. . . . However, if plaintiff were to admit to being in the United States illegally or were to refuse to answer questions regarding his [immigration] status on the grounds that it is not relevant, then the issue of his standing would properly be before us, and we would address the issue of whether Hoffman Plastics [sic] applies to ADA claims for compensatory and punitive damages brought by undocumented aliens. ${ }^{64}$

In other words, if the court had been able to decide this issue, the employee would have suffered the same fate as Mr. Castro did in Hoffman, where his undocumented status negated recovery from his employer even though his employer violated the law. Similarly, because of his undocumented status, Mr. Lopez would not have been able to recover from his employer for a violation of the ADA. Furthermore, if Mr. López had not withdrawn his request for backpay, the court very possibly would also have precluded that remedy. The evidence for this assertion is the Lopez court's careful note of the Hoffman Court's language that "awarding backpay not only trivializes the immigration laws, it also condones and encourages future violations." 65

\section{State Supreme Court Cases: Worker's Compensation}

Following the Supreme Court's decision in Hoffman Plastic Compounds, the highest courts in three states (Pennsylvania, Minnesota and Michigan) have considered the applicability of their worker's compensation statutory schemes

60. Mr. López, an employee with kidney disease, had been laid off without determining whether he could perform his old job or another job at the same employer. $I d$. at *2.

61. Id.

62. Id. at *7.

63. Id. at $* 3$.

64. Id. at *7-8.

65. Id. at *6. 
to undocumented workers. ${ }^{66}$ These three cases have, again, evidenced a mixed result, where the tensions Hoffman raised regarding the employment of undocumented workers and their ability to recover for workplace injuries, ${ }^{67}$ are clearly palpable in the strong dissents of each of the three opinions.

The Supreme Court of Pennsylvania decided a case where an employer, Reinforced Earth Company, argued that a worker's lack of work authorization vitiated his entitlement to compensation benefits for injuries suffered at his place of employment. ${ }^{68}$ The court rejected the employer's argument because it was prohibited from making any extra-statutory declaration of public policy or judicial legislation to exclude undocumented workers from the reach of the worker's compensation system. ${ }^{69}$ The court also held that an employer is not required to show job availability when seeking to suspend worker's compensation benefits granted to an employee who is an unauthorized alien. ${ }^{70}$ Thus, in this case the public policy behind the worker's compensation systema bilateral compact that assures the redress of worker's injuries while the worker gives up the right to sue his employer-won the day over the immigration law policy against the hiring of undocumented workers that the IRCA contains.

Although the opinion of the Pennsylvania Supreme Court in Reinforced Earth did not directly address, or even cite, Hoffman, the lone dissent of Justice Newman did use Hoffman to assert that the public policy of redressing the work-related injuries of employees, as enunciated in Pennsylvania's Worker's Compensation statutes should yield to the IRCA's congressional policy against the hiring of unauthorized workers. ${ }^{71}$ Justice Newman would have had the majority in Reinforced Earth faithfully follow Hoffman, noting that the Supreme Court's decision "illustrates that where two legislative schemes apply to the same situation, one may have to yield to the higher policy interests served by the other." ${ }^{, 72}$ In other words, in Justice Newman's view, the Pennsylvania Worker's Compensation policy of redressing the injuries of undocumented workers is of lower value to society than the IRCA's policy of not hiring

66. See Reinforced Earth Co. v. Worker's Comp. Appeal Bd. (Astudillo), 810 A.2d 99, 102 (Pa. 2002); Correa v. Waymouth Farms, Inc., 664 N.W.2d 324 (Minn. 2003); Sánchez v. Eagle Alloy, Inc., 671 N.W.2d 874 (Mich. 2003) vacated by 684 N.W.2d 342 (Mich. 2004).

67. It should be noted that foreign born workers most often work in dangerous occupations such as construction and manufacturing, and in fact have higher rates of job injuries and fatalities than native born workers. See Rebecca Smith, Amy Sugimori \& Luna Yasui, Low Pay: High Risk: State Models for Advancing Immigrant Workers Rights, 28 N.Y.U. REv. L. \& Soc. Change 597, 599 (2004) (citing a Department of Health and Human Services study showing an increase in fatal injuries to foreign born workers and Latinos).

68. Reinforced Earth Co., 810 A.2d at 102.

69. Id. at 105 .

70. Id. at 107 .

71. Id. at 112 (Newman, J., dissenting).

72. Id. at 110 (Newman, J., dissenting). 
undocumented workers, and thus, it should yield to that higher immigration policy. $^{73}$

According to Justice Newman, there should be no compensation for an injured worker who suffered an accident that rendered him unconscious, left him with a concussion, head injury, and acute cervical and lumbar-sacral strain and sprain, ${ }^{74}$ because of his act of obtaining employment with fraudulent documentation. This of course is the extra-statutory declaration of public policy or judicial legislation in which the Reinforced Earth majority clearly refused to engage, emphasizing that the Pennsylvania General Assembly had not statutorily excluded undocumented workers from the purview of its Worker's Compensation Act. ${ }^{75}$

The Supreme Court of Minnesota similarly considered the appeal of an employer whose employee, an undocumented worker, received on the job injuries and was collecting temporary total disability payments. ${ }^{76}$ The employer argued that the worker would not be able to conduct a diligent job search, as required by the statute for continued benefits, because his undocumented status would preclude him from obtaining employment without violating IRCA. ${ }^{77}$ The Minnesota Supreme Court did not agree, relying on the Minnesota worker's compensation statutory language as well on the language of IRCA, which expressly failed to preclude payment of temporary total disability

73. The employer had argued at the Pennsylvania Commonwealth Court, which was the court below, that the IRCA preempted its state Worker's Compensation law, so that the undocumented worker could not be considered an "employee" to receive benefits under the law. Id. at $103, \mathrm{n} .5$. The Commonwealth Court had rejected the argument, finding no preemption. Id. The Supreme Court of Minnesota has also rejected the argument that IRCA preempts its state Worker's Compensation statute, finding that IRCA was not aimed at impairing state labor law protections. Correa v. Waymouth Farms, Inc., 664 N.W.2d 324, 329 (Minn. 2003). Two courts of appeal have similarly rejected the argument that IRCA preempts state Worker's Compensation remedies with regard to undocumented workers. The Georgia Court of Appeals has consistently expressed its view that there is no conflict between IRCA and its state Worker's Compensation statute, so that an employer could not deny benefits under the statute to an undocumented worker. See Wet Walls, Inc.v. Ledezma, 598 S.E.2d 60, 63 (Ga. Ct. App. 2004); see also, Continental PET Technologies v. Palacias, 604 S.E.2d 627, 334 (Ga. Ct. App. 2004) (en banc). Earth First Grading v. Gutierrez, 606 S.E.2d 332, 334 (Ga. Ct. App. 2004). Similarly, because IRCA does not contain express preemption language, a Florida appellate court found that an undocumented worker would not be precluded from obtaining Worker's Compensation in that state. See Safeharbor Employer Serv. I. Inc. v. Cinto Velázquez, 860 So.2d 894, 896 (Fla. Ct. App. 2003). The preemption argument usually made and rejected with regard to IRCA in such cases is based on the Congress's authority over immigration law matters. See U.S. CONST. art. VI, cl.2. Congress has the power to "establish an uniform Rule of Naturalization." See U.S. CoNST. art. I, § 8, cl. 4. The Supreme Court has found that the federal government's inherent sovereign power allows it to further regulate in the field of immigration. See United States ex rel. Knauff v. Shaughnessy, 338 U.S. 537, 542 (1950).

74. Reinforced Earth Co., 810 A.2d at 101.

75. Id. at 105.

76. Correa v. Waymouth Farms, Inc., 664 N.W.2d 324 (Minn. 2003).

77. Id. at 328. 
payments. $^{78}$ The Court explicitly declined to address the public policy questions the employer raised, stating that "if policy considerations favor a different result, that determination is more properly left to the legislature to make."79

However, there was a strong dissent to the opinion from Justice Gilbert, who stated that the majority ignored the IRCA, an "important federal immigration requirement," by "creating a legal fiction of a diligent job search that is contrary to federal law." 80 Justice Gilbert used the Hoffman language, stating that the majority's holding "trivializes" immigration law, because the undocumented worker would have to conduct any job search through fraud and deception as to immigration status. ${ }^{81}$

Finally, in late 2003, the Supreme Court of Michigan granted the application for leave to appeal of an undocumented worker to whom the lower court had denied worker's compensation benefits. ${ }^{82}$ The Court even invited amicus curiae briefs. ${ }^{83}$ Although the Court of Appeals of Michigan held that the state's worker's compensation statute applied to undocumented workers, it found that the undocumented worker's criminal act of obtaining employment fraudulently mandated the denial of the worker's compensation benefits. ${ }^{84}$ After consideration of the case for more than six months, the Michigan Supreme Court asserted that it was no longer persuaded that it should review the questions presented. ${ }^{85}$ The court's action was criticized in dissent by two justices. Justice Kelly disagreed, finding jurisprudential and policy significance of the case. ${ }^{86}$ Justice Markman noted that the decision of the court of appeals was a compromise that left many questions unanswered, and he highlighted the case's importance not only for the undocumented, "but equally for the rule of law and the meaning of citizenship. ${ }^{, 87}$

Thus, in the three years following Hoffman much litigation has ensued, ${ }^{88}$ with employers arguing for an expansion of the decision's reach at both the state and federal level. There have been mixed results throughout, and

78. Id. at 331 .

79. Id.

80. Id. (Gilbert, J., dissenting).

81. Id. at 332 (Gilbert, J., dissenting).

82. Sanchez v. Eagle Alloy, Inc., 671 N.W.2d 874 (Mich. 2003) vacated by 684 N.W.2d 342 (Mich. 2004).

83. Id.

84. Sánchez v. Eagle Alloy, Inc., 658 N.W.2d 510, 515 (Mich. Ct. App. 2003).

85. Sánchez v. Eagle Alloy, Inc., 684 N.W.2d 342 (Mich. 2004). The effect of this order is that the published opinion of the Court of Appeals was left as binding precedent. Id. (Weaver, J., concurring).

86. Id. (Kelly, J., dissenting). Justice Kelly stated that "[t]he parties, the people of Michigan, and those who come into the state to work have a pressing interest in having these issues resolved by the state's highest court." $I d$.

87. Id. at 345 (Markman, J., dissenting). In fact, Justice Markman noted that "no other case has engendered more passionate debate ...." Id. at 343 (Markman, J., dissenting).

88. The Hoffman decision has been cited in 62 subsequent court decisions. See SHEPARD's UNITED STATES CITATIONS (Mar. 29, 2005). 
sometimes employers have not fared particularly well in having courts adopt a wide view that would leave undocumented workers with little or no labor law protections in the workplace.

Nevertheless, lower federal courts have resolved several of the cases on pretrial motions and have not addressed their merits, so that the final resolution of many of these Hoffman challenges remains to be seen. Furthermore, considering the time and resources spent by immigrants and their advocates defending these kinds of lawsuits, the undocumented workers' lives and working conditions are no better post-Hoffman, because the organizing and advocacy of labor and immigrants' rights groups has shifted to a defensive, rather than proactive, role to further the rights of undocumented workers in the United States.

\section{CURRENT STATUTORY REGIMES AND CASE LAW REGARDING UNDOCUMENTED WORKERS}

Undocumented workers are not universally protected in the workplace under U. S. law. Judicial, legislative, and administrative bodies have placed limitations upon the protection of the undocumented worker in the workplace in various contexts, as these entities struggle to reconcile labor law and policy with immigration law and policy. This phenomenon is evidence of the dual nature of the undocumented worker as both an outsider and insider to the U.S. community. ${ }^{89}$

\section{A. NLRA}

The NLRA statutory definition of "employee" does not exclude undocumented workers. Therefore, they fall under the purview of the NLRA. ${ }^{90}$ In particular, undocumented workers are able to vote in union elections under the NLRA without regard to their immigration status. ${ }^{91}$ The NLRA also protects undocumented workers against unfair labor practices. ${ }^{92}$ An employer commits an unfair labor practice by reporting undocumented workers to the INS (now Department of Homeland Security or DHS) in retaliation for participating in union activities. ${ }^{93}$ Prior to Hoffman, the undocumented worker had been allowed backpay, albeit in a restricted manner, as decided by the Supreme Court in the Sure-Tan case. ${ }^{94}$

89. Bosniak, supra note 1, at 956 (discussing the dual identity of undocumented workers in the United States after IRCA, as "they are both outsiders and members, regulated objects of immigration control and subjects of membership in limited but important respects.").

90. Sure-Tan, Inc. v. NLRB, 467 U.S. 883, 891 (1984).

91. See Chicago Future, Inc. v. NLRB, No. 13-CA-40392, 2003 LEXIS NLRB 93, n.4 (N.L.R.B. Mar. 12, 2003).

92. See NLRB General Counsel Memorandum No. GC 02-06, Procedures and Remedies for Discriminatees Who May Be Undocumented Aliens after Hoffman Plastic Compounds, Inc. (July 19, 2002), 2002 WL1 730518 [hereinafter NLRB General Counsel Memorandum].

93. Sure-Tan Inc., 467 U.S. at 894.

94. Id. at 902-3. See also supra notes 20-24 and accompanying text. 
After Hoffman, the NLRB has stated that it will object if employers "attempt to elicit evidence concerning an employee's asserted undocumented status in order to escape unfair labor practice liability." 95 Furthermore, with regard to undocumented workers, the NLRB has instructed its regional offices that:

Regions have no obligation to investigate an employee's immigration status unless a respondent affirmatively establishes the existence of a substantial immigration issue. Regions should begin their analysis with the presumption that employees and employers alike have conformed to the law. The law-IRCA-protects employees against harassment by an employer which seeks to reverify their immigration status without cause. A substantial immigration issue is lodged when an employer establishes that it knows or has reason to know that a discriminatee is undocumented. Once an employer makes this showing, Regions should investigate the claim by asking the Union, the charging party and/or the discriminatee to respond to the employer's evidence. Again, a mere assertion is not a sufficient basis to trigger such an investigation. ${ }^{96}$

Hoffman has modified the NLRB remedial scheme by removing backpay as a remedy for an unfair labor practice for undocumented workers. ${ }^{97}$ This modification has resulted in changes to NLRB policy regarding the remedies the Board will seek for undocumented workers, but not in the manner in which NLRB conducts its investigations of unfair labor practices. ${ }^{98}$

A recent NLRB case extends this result. In re Tuv Taam Corporation is a NLRB unfair labor practice case in which the Board refused to consider the immigration status of the discriminated employees until after the determination of the employer's liability. ${ }^{99}$ The Board's rationale was that the immigration status of the discriminated employees had no bearing on the issue of whether the employer has engaged in an unfair labor practice. ${ }^{100}$ Thus, the NLRB has limited Hoffman to its most restrictive holding. Bearing in mind that the majority in Hoffman was criticized by the dissent for failing to pay the requisite

95. NLRB General Counsel Memorandum, supra note 92.

96. Id.

97. Hoffman Plastic Compounds, Inc. v. NLRB, 535 U.S. 137, 150 (2002).

98. NLRB General Counsel Memorandum, supra note 92.

99. In re Tuv Taam Corp., 340 NLRB No. 86, 2003 WL 22295361, *6 (N.L.R.B. Sep. 30, 2003). In fact, the Board ordered conditional backpay as a remedy at this stage of the proceeding. See id at $* 7$.

100. Id. 
deference to the NLRB's own administrative opinion at the Board level, ${ }^{101}$ this result is hardly surprising.

\section{B. FLSA}

There is consensus among the courts, before and after IRCA ${ }^{102}$ and after Hoffman, ${ }^{103}$ that undocumented workers are entitled to FLSA wage and hour enforcement remedies, including backpay, which is unpaid wages for work already performed. ${ }^{104}$ The legislative history of IRCA explicitly supports this conclusion. ${ }^{105}$ Yet at least one court has indicated that it will not allow a wage claim in a case where the worker obtained his employment in violation of IRCA. ${ }^{106}$

The United States Department of Labor has indicated that it will maintain its practice of full enforcement of the FLSA, without taking into account whether the employee is undocumented, on the theory that enforcement of the wage claims for work actually performed is different from the backpay remedy precluded in Hoffman. ${ }^{107}$ This policy statement also includes enforcement of the Migrant and Seasonal Agricultural Worker Protection Act (AWPA). ${ }^{108}$

In summary, two norms are now evident with regard to allowing the undocumented worker to pursue wage claims under the FLSA. First, the immigration status of the claimant will most likely be undiscoverable, based on the fact that allowing discovery into this area would have a chilling effect on the filing of wage claims. ${ }^{109}$ Second, the Hoffman decision generally will not

101. See supra notes 35-37 and accompanying text (discussing Justice Breyer's view in the Hoffman dissent regarding the majority's lack of deference to the NLRB in the Hoffman decision).

102. See generally Richard E. Blum, Labor Standards Enforcement and the Realities of Labor Migration: Protecting Undocumented Workers afier Sure-Tan, The IRCA and Patel, 63 N.Y.U. L. REV. 1342, 1355 (1988) (discussing cases before and after IRCA where FLSA protections were afforded to undocumented workers, in particular, the Eleventh Circuit Court of Appeals, which decided Patel v. Quality Inn South, 846 F.2d 700 (11 th Cir. 1988), holding that the undocumented worker was "entitled to the full range of available remedies under the FLSA without regard to his immigration status").

103. See supra notes $38-47$ and the cases cited therein:

104. See Blum, supra note 102, at 1344.

105. See id. at 1368 (discussing how IRCA was not meant to preclude FLSA and other labor law protections).

106. See Ulloa v. Al's All Tree Serv., 768 N.Y.S.2d 556, 558 (N.Y. D. Ct. 2003). This result stands in contrast to the New York Attorney General's view regarding state wage payments, where they would be enforced for undocumented workers. See Op. Att'y Gen. 2003F3 (N.Y. Oct. 21, 2003), 2003 WL 22522840.

107. See U.S. Department of Labor, Employment Standards Division, Application of U.S. Labor Laws to Immigrant Workers: Effect of Hoffman Plastics Decision on Laws Enforced by the Wage and Hour Division (Fact Sheet \#48) (Aug. 14, 2002), available at http://www.dol.gov/ esa/regs/compliance/whd/whdfs48.htm (last visited Dec. 30, 2004), and cases cited therein.

108. Id. The AWPA is codified at 29 U.S.C. $\$ 1801$ et. seq. (2000).

109. See supra notes 38-47 and cases cited therein. See also Cabrera v. Ekema, No. 250854, 2005 Mich. App. LEXIS 616 (Mich. Ct. App. March 10, 2005) (denying discovery 
bar recovery of wage claims, ${ }^{110}$ a policy that reduces the incentives for unscrupulous employers from knowingly hiring undocumented workers and taking a chance of violating the FLSA and IRCA in the hope that the employees' undocumented status will bar their recovery of wages for work already performed. ${ }^{111}$

\section{Anti-Discrimination Laws: The ADA, Title VII, and State Anti- Discrimination Laws}

Lopez $v$. Superflex, ${ }^{112}$ is the only post-Hoffman reported case concerning an undocumented worker claiming discrimination under the ADA. The court did not reach the merits, but it is clear that it would certainly have denied the undocumented worker any remedies had the issue been before the court. ${ }^{113}$

Prior to the IRCA, courts interpreted the other main federal antidiscrimination statute, Title VII, as affording protection to undocumented workers. ${ }^{114}$ After the IRCA, however, the Fourth Circuit Court of Appeals held en banc that because undocumented workers are ineligible for employment in the United States, they are ineligible for Title VII remedies. ${ }^{115}$

In at least one post-Hoffman Title VII reported opinion, ${ }^{116}$ the court did not require the employee to disclose his immigration status. Thus, the court did not decide the case on the merits; however, the court gave indications of not finding Hoffman dispositive on the availability of backpay as a remedy for violations of Title VII. ${ }^{17}$ The Ninth Circuit Court of Appeals reaffirmed this view in Rivera $v$. NIBCO, Inc., ${ }^{118}$ where, in an interlocutory appeal, the court held that an employer's discovery request as to the former employee's

regarding worker's Social Security number in suit under FLSA).

110. See supra note 102 and case cited therein.

111. Recent research has shown that the industries in which the undocumented workers are mostly laboring are among those that are most represented in wage claims violations. See Smith et al., supra note 67, at 600 (citing survey by the Department of Labor showing that in the year 2000,100 percent or all poultry processing plants surveyed were found to be noncompliant with federal wage and hour laws).

112. López v. Superflex, Ltd., No. 01-Civ.-10010(NRB), 2002 U.S. Dist. LEXIS 15538 (S.D.N.Y. Aug. 21, 2002).

113. See supra notes 59-65 and accompanying text for a discussion of López.

114. See generally María Ontiveros, To Help Those Most In Need: Undocumented Workers' Rights and Remedies under Title VII, 1994 N.Y.U. REV. L. \& SOC. CHANGE 608, 614 (1994) (discussing cases regarding Title VII coverage of undocumented workers).

115. See Egbna v.Time-Life Libraries, 153 F.3d 184, 186 (4th Cir. 1997) (en banc).

116. See De La Rosa v. N. Harvest Furniture, 210 F.R.D. 237 (C.D. Ill. 2002).

117. See supra notes 48-54 and accompanying text for a discussion of De La Rosa. In another recent decision, EEOC's motion to deny the employer pretrial access to the immigration status of the charging parties was granted based on the court's view that failure to do so "would significantly discourage employees from bringing actions against their employers who engage in discriminatory employment practices." EEOC v. First Wireless Group, 225 F.R.D. 404, 406 (E.D.N.Y. 2004). The court in this case explicitly rejected the employer's argument that any restriction based on such an in terrorem effect is the province of the legislature. Id. at 407.

118. Rivera v. NIBCO, Inc., 364 F.3d 1057 (9th Cir. 2004), reh'g denied, 384 F.3d 822 (9th Cir. 2004), cert. denied., 73 U.S.L.W. 3415, 2005 WL 517010 (2005). 
immigration status in a Title VII case placed an undue burden on the party bringing the claim. ${ }^{119}$ Although the issue of backpay was not before the court, it nevertheless asserted that its interpretation of Hoffman's prohibition of backpay under NLRA did not serve to prohibit a district court from awarding backpay to a Title VII plaintiff. ${ }^{120}$ This assertion, however, was subject to strong criticism by the dissent in the denial of a rehearing en banc of this case. Judges Bea, Kozinski, Kleinfield, and Gould dissented in a lengthy and well articulated opinion, stating:

The panel's decision allows a plaintiff who claims that racially discriminatory firing caused backpay and frontpay lost wages, to refuse to answer deposition questions touching on her place of birth and immigration status. Thus, the panel's decision impedes the ascertainment of the truth in advance of trial, thereby profoundly subverting the purposes of liberal discovery in civil cases. The decision also frustrates the purposes of national immigration policy: to limit employment benefits to American citizens and foreign persons authorized to work in this country. ${ }^{121}$

The dissenters' characterization of national immigration policy as limiting employment benefits only to U.S. citizens and authorized noncitizens is particularly striking for its extensiveness. Although the dissent does not define the term "employment benefits," one can imagine that any common interpretation of the term would virtually erode any state or federal labor or employment law protection for undocumented workers.

The dissent recognized the realities of the litigation process between an undocumented worker and his or her employer, noting that:

It may be tempting to increase the settlement value or the award of a minority worker's racial discrimination lawsuit by allowing her to include claimed lost wages and bar questioning of her immigration status. After all, the employer hired her and benefited from her labor. While she was working, the employer did not dig too deep into whether her papers were in order. Now that she asserts her civil rights against the employer's claimed discriminatory firing, the employer gets righteous, and for all the wrong reasons. ${ }^{122}$

119. Id. at 1074.

120. Id.

121. See Rivera v. NIBCO, Inc. 384 F.3d 822, 823-4 (9th Cir. 2004) (Bea, J., dissenting), cert. denied., 73 U.S.L.W. 3415, 2005 WL 517010 (2005).

122. Id. 
The Rivera dissenters to the denial of rehearing en banc further cited Hoffman and recognized that "[i]f estoppel by the employer's acts could bar enforcement of our country's Immigration [sic] laws, the panel's opinion might not be so objectionable. Of course, we know such private conduct cannot frustrate explicitly stated congressional public policy . ..."123 In other words, the dissenters to the denial of rehearing en banc were also concerned about the realities of the employment relationship between the undocumented worker and the employer, particularly where an employer might be aware of the worker's unauthorized status and deriving benefit from his work.

Finally, the dissenters exposed the policy concerns and dangers of the Rivera approach and highlighted that:

We risk corrupting an admirable civil rights policy to prevent discrimination when we rely on evasions to enforce it. . . The fact is that if plaintiffs do not have authorized immigration status, they are not entitled to be awarded back wages or wages they might have earned in the future from a job which they were incapable of holding, under our Immigration laws. ${ }^{124}$

The words of the ninth circuit dissenters to the denial of rehearing en banc in Rivera clearly exemplify the tensions inherent in the difficult relationship among the undocumented worker, the often unscrupulous employer, and the United States polity.

The United States Supreme Court recently denied certiorari in Rivera, leaving the ninth circuit opinion as binding precedent. ${ }^{125}$ There were no dissenters to the denial of certiorari and no written opinion of any kind with regard to the case. Since it is the first time the Supreme Court has reviewed remedies for undocumented workers following Hoffman, anecdotal reports suggest that it is seen as an omen for the labor law rights of undocumented workers in the United States.

However, the view of ninth circuit dissenters to the denial of rehearing en banc in Rivera found support in Escobar v. Spartan Security Service, a Title VII sexual harassment case where a lower federal court granted summary judgment and denied backpay to an undocumented worker based on Hoffman. ${ }^{126}$ The court found that it was foreclosed from doing so by Hoffman's rationale that an undocumented worker may not receive a backpay award as a

123. Id. (Bea, J., dissenting) (citation omitted).

124. See id. (citations omitted).

125. NIBCO, Inc. v. Rivera, 73 U.S.L.W. 3529, 2005 WL 517010 (Mar. 7, 2005). As noted supra at note 55, the Supreme Court's denial of certiorari could be analyzed to reflect a lack of "intense dissatisfaction" of the majority of the Justices with the decision below. See Peter Linzer, The Meaning of Certiorari Denials, 79 CoLUM. L. REV. 1227, 1229 (1979).

126. Escobar v. Spartan Security Serv., 281 F. Supp. 2d. 895, 897 (S.D. Tex. 2003). 
remedy, since it would represent earnings that he could not legally have earned. ${ }^{127}$

However, the federal agency charged with the enforcement of Title VII views Hoffman differently. Almost immediately after Hoffman, the Equal Employment Opportunity Commission (EEOC) indicated that it "will evaluate the effect Hoffman may have on the availability of monetary remedies to undocumented workers under the federal employment discrimination statutes." ${ }^{128}$ The EEOC has further asserted:

The Supreme Court's decision in Hoffman in no way calls into question the settled principle that undocumented workers are covered by the federal employment discrimination statutes and that it is as illegal for employers to discriminate against them as it is to discriminate against individuals authorized to work. When enforcing these laws, EEOC will not, on its own initiative, inquire into a worker's immigration status. Nor will EEOC consider an individual's immigration status when examining the underlying merits of a charge. The Commission will continue vigorously to pursue charges filed by any worker covered by the federal employment discrimination laws, including charges brought by undocumented workers, and will seek appropriate relief consistent with the Supreme Court's ruling in Hoffman. Enforcing the law to protect vulnerable workers, particularly low income and immigrant workers, remains a priority for EEOC. ${ }^{129}$

Thus, the coverage and enforcement of the anti-discrimination laws under the EEOC's purview has remained the same after Hoffman. It is only in the availability of remedies that the administrative agency has to implement changes wrought by the court decisions denying compensation to undocumented workers. The EEOC's policy, however, will effectively cause the agency to investigate claims, in an effort to protect the vulnerable workers in our midst, where there might be no remedy because of these court decisions limiting such remedies.

At least two state courts have taken a more expansive view of Hoffman's reach. Recently in a state court under a state anti-discrimination statute denied an undocumented worker recovery using Hoffman. In Crespo v. Evergo

127. Id.

128. U.S. Equal Employment Opportunity Commission, Rescission of Enforcement Guidance on Remedies Available to Undocumented Workers Under Federal Employment Discrimination Laws, at http://www.eeoc.gov/policy/docs/undoc-rescind.html (June 27, 2002) (last visited Dec. 30, 2004).

129. Id. 
Corp., ${ }^{130}$ the Superior Court of New Jersey affirmed the trial court's denial of economic damages, including backpay, to an undocumented worker suing for wrongful termination under New Jersey's Law Against Discrimination (LAD). ${ }^{131}$ The court also dismissed the complaint in its entirety, holding that in light of Hoffman's strong enforcement of the policies that the IRCA served, the plaintiff's statutory bar to employment precluded her eligibility for various economic and non economic remedies. ${ }^{132}$

In an unpublished opinion, another state court denied an undocumented worker recovery for discrimination based on medical condition, physical disability and wrongful termination under its state antidiscrimination statute. ${ }^{133}$ The court cited Hoffman and found that the unclean hands doctrine precluded recovery of an employee who presented false documents to be hired in the first place. ${ }^{134}$ The result then is that with regard to recovery for undocumented workers under Title VII and state antidiscrimination statutes, the period post Hoffman has seen both cases allowing and cases denying recovery for the worker. It is the case that the future is yet to come, and certainly the denial of certiorari in Rivera will likely be seen to represent the dominant trend in this area.

\section{Worker's Compensation}

In general, worker's compensation compensates employees who are injured on the job in exchange for their renunciation of the ability to sue the employer; the statutory schemes vary from state to state. As to the treatment of undocumented workers, from the coverage of the law to allowing of benefits for the undocumented workers, the prevailing trend favors the undocumented worker. In Texas, for example, undocumented workers have not been found to be precluded from compensation, both pre ${ }^{135}$-and post-IRCA and Hoffman. Similarly, post-IRCA, courts have found that undocumented workers are entitled to worker's compensation benefits in California, ${ }^{136}$ Connecticut, ${ }^{137}$ Louisiana, ${ }^{138}$ New Jersey, ${ }^{139}$ New York, ${ }^{140}$ Oklahoma, ${ }^{141}$ Minnesota, ${ }^{142}$ and

130. Crespo v. Evergo Corp., 841 A.2d 471 (N.J. Super. Ct. App. Div. 2004).

131. N.J. STAT. ANN. \& 10:5-1-10:5-42 (West 2004).

132. Crespo, 841 A.2d. at 401.

133. Morejon v. Hinge, No. BC255537, 2003 WL 22482036 at *1 (Ca. Ct. App., Nov. 21 , 2003).

134. Id. at $* 10$.

135. See Commercial Standard Fire \& Marine Co. v. Galindo, 484 S.W.2d. 635 (Tex. App. 1972). Florida is another state that allowed undocumented employees worker's compensation benefits pre-IRCA since its statute includes "aliens" as employees. See Gene's Harvesting v. Rodriguez, 421 So. 2d 701 (Fla. Dist. Ct. App. 1982). 2000).

136. See Del Taco v. Worker's Comp. Appeals Bd., 94 Cal. Rptr. $2 d 825$ (Cal. Ct. App.

137. See Dowling v. Slotnik, 712 A.2d 396 (Conn. 1998).

138. See Artiga v. Patout, 671 So. $2 d 1138$ (La. Ct. App. 1996). 
Virginia. ${ }^{143}$ Pennsylvania and Minnesota have also allowed, under supreme court opinions, undocumented workers to obtain worker's compensation benefits post-Hoffman. ${ }^{144}$ Other states that allow the undocumented to obtain worker's compensation post-Hoffman include Florida, ${ }^{145}$ Ohio, ${ }^{146}$ and Oklahoma. ${ }^{147}$ Thus, in the worker's compensation area, the undocumented status of the injured employee has been evaluated by courts in different states before IRCA, which banned the employment of undocumented workers, after IRCA, and after Hoffman.

Virginia is a special case because its supreme court denied benefits to an undocumented worker in 1999. Its rationale was to attempt to reconcile its state worker's compensation law with the IRCA. ${ }^{148}$ Shortly thereafter, the general assembly overrode the governor's veto, and passed legislation that gave worker's compensation coverage to undocumented workers. ${ }^{149}$

There are states that have limited or denied the availability of worker's compensation post-IRCA and post-Hoffman. For example, a court denied an undocumented worker in Nevada vocational rehabilitation benefits post-IRCA because of his unauthorized entry into the United States and his inability to work under IRCA. ${ }^{150}$ Post-Hoffman, courts have denied worker's compensation to undocumented workers in Pennsylvania ${ }^{151}$ and Michigan. Michigan used Hoffman to limit benefits from the date of discovery of an immigrant worker's undocumented status based on the crime of working in violation of IRCA. ${ }^{152}$ Thus, in the area of worker's compensation, there has been a trend to allow recovery by the undocumented worker, although it is not a uniform rule. There have been varying results based on the statutory definition of "employee," but overall the negative effect of Hoffman has been less pronounced in this area. This is probably attributable to the state law analysis that the courts undertake in deciding whether an injured undocumented worker can obtain compensation for workplace injuries.

139. See Mendoza v. Monmouth Recycling Corp., 672 A.2d 221 (N.J. Super. Ct. App. Div. 1996).

140. See N.Y. WORKERS' COMP. LAW $\$ 17$ (McKinney 2004).

141. See Lang v. Landeros, 918 P.2d 404 (Okla. Ct. App. 1996).

142. See Correa v. Waymouth Farms, Inc., 664 N.W.2d 324 (Minn. 2003).

143. H.B. 1036, 2000 Gen. Assem., Reg. Sess. (Va. 2000).

144. See supra Part II.B. and cases cited therein.

145. See Safeharbor Employer Serv. I, Inc. v. Cinto Velazquez, 860 So. 2 d 984 (Fla. Dist. Ct. App. 2003).

146. See Rajeh v. Steel City Corp., 813 N.E.2d 697 (Ohio Ct. App. 2004).

147. See Cherokee Indus., Inc. v. Alvarez, 84 P.3d 798 (Okla. Civ. App. Okla. 2003).

148. Granados v. Windson Dev. Corp., 509 S.E.2d 290 (Va. 1999).

149. H.B. 1036, 2000 Gen. Assem., Reg. Sess. (Va. 2000).

150. Tarango v. State Indus. Ins. Sys., 25 P.3d. 175 (Nev. 2001).

151. See Mora v. DDP Contracting Co., 845 A.2d 950 (Pa. Commw. Ct. 2004).

152. Sanchez v. Eagle Alloy, Inc., 658 N.W.2d 510 (Mich. Ct. App. 2003). 


\section{E. Tort and Other Forms of Recovery}

In actions for damages in tort cases, whether courts will allow an undocumented worker to recover for injuries will vary from state to state. Some courts have construed the Hoffman decision narrowly, while others have applied the ruling in a more generalized manner. In Florida, a federal district court granted an employer's motion for summary judgment, denying an award of lost wages to the estate of an undocumented laborer who died from injuries sustained in a forklift accident at a construction site. ${ }^{153}$ Relying on Hoffman, the court reasoned that awarding lost wages would be equivalent to violating the IRCA. ${ }^{154}$ The court's conclusion that awarding lost wages is inconsistent with the decision in Hoffman stems from its equation of backpay and lost wages, because both are awards for work never performed. ${ }^{155}$

The Southern District of New York departed from Florida's view, adopting a more limited interpretation of Hoffman by holding that an injured subcontractor's employee's alien status did not deprive the employee of his right to lost wages. ${ }^{156}$ The court noted that, unlike Hoffman, this case involved a claim for relief under state, not federal, law. ${ }^{157}$ The court noted that the employee's immigration status was relevant in making a determination of whether an award for lost wages was appropriate; however, it also acknowledged that undocumented persons do in fact obtain employment in the United States. ${ }^{158}$ As a matter of New York's public policy, the court did not find that injured workers are barred from compensation in the form of backpay. ${ }^{159}$ Similarly, in Cano v. Mallory, ${ }^{160}$ a New York state court post Hoffman found that the undocumented status of an injured worker was not a bar to the civil action. Yet, it allowed the jury to consider the worker's undocumented status with regard to the issue of lost wages, but not regarding the issue of pain and suffering. This is but an example of the mixed results courts have reached following Hoffman. ${ }^{161}$

However, most recently in New York two lower companion cases limited the availability of remedies for injured undocumented workers filing personal injury lawsuits for workplace related injuries. ${ }^{162}$ The undocumented workers

153. Veliz v. Rental Serv. Corp. USA, 313 F.Supp. 2d 1317, 1337 (M.D. Fla. 2003).

154. Id. at 1336.

155. Id. at 1337.

156. Madeira v. Affordable Hous. Found. Inc., 315 F.Supp. 2d 504, 507 (S.D.N.Y. 2004).

157. Id.

158. Id.

159. Id.

160. Cano v. Mallory Mgmt., 760 N.Y.S. 2d. 816 (N.Y. Sup. Ct. 2003).

161. See id.

162. See Sanango v. 200 E. 16th St. Hous. Corp.,No. 2571, 2004 N.Y. App. Div. LEXIS 15637 (N.Y. Sup. Ct. Dec.28, 2004); Balbuena v. IDR Realty, Inc., No. 2191, .2004 N.Y. App. Div. LEXIS 15627 (N.Y. Sup. Ct. Dec. 28, 2004). In an unpublished case decided days earlier, another division of the New York Supreme Court found that the plaintiff's undocumented status should not be a bar to recovery but only a factor for the jury to consider when determining 
were allowed to pursue damages by the trial court for pain and suffering. ${ }^{163}$ However, following Hoffman and its interpretation of IRCA's policy, the court found that the worker's undocumented status restricted the damages award for lost earnings to the amount he would have earned in his home country, since "an award based on a prevailing foreign wage would not offend any federal policy." 164 There was vigorous dissent by Judge Ellerin, who asserted that the legislative history of IRCA indicated that Congress did not intend to preempt state common law on the availability of damages for lost wages in tort actions. ${ }^{165}$ The view expressed by Judge Ellerin's dissent has been followed by the Court of Appeals in Texas in allowing an injured undocumented worker to present evidence to recover damages for lost earnings, finding that Hoffman and its view of IRCA did not apply to state common law personal injury damages. ${ }^{166}$

With regard to other forms of recovery, post Hoffman, the Tennessee Court of Appeals allowed an employee to recover damages for breach of contract and intentional misrepresentation when he was hired and brought to the United States legally by a company which subsequently did not file his immigration documents, at which time he became undocumented. ${ }^{167}$ The court declined to extend Hoffman to such a case, finding it inapplicable because it was based on a "delicate balance of immigration law and labor law" under the NLRA. ${ }^{168}$

As seen above, a review of the main statutes and court decisions affecting undocumented workers in this country reveals a hostile inconsistency, ${ }^{169}$ where they are sometimes afforded remedies and other times they are not, based on predictable positions with regard to Hoffman. Table 1 below sets forth a selected summary of the current remedies available to undocumented workers under different statutory regimes. Using IRCA and its statement of the public policy against the hiring of undocumented workers, and following Hoffman, these provisions and decisions often neglect the real effects on the working

entitlement to future lost wages. See Celi v. 42nd St. Dev. Project, Inc., No. 37491/01, 2004 WL 281902, *3 (N.Y. Sup. Ct. Nov. 9, 2004). An earlier case had refused to extend Hoffman to include state law tort remedies and denied discovery requested by employer to ascertain the worker's citizenship and tax records. See Llerena v. 302 W. 12th St. Condo., No. 102490/03, 2004 WL 279316, *2 (N.Y. Sup. Ct. Oct. 7, 2004).

163. Sanango, 2004 N.Y. App. Div. LEXIS 15637 at *2-3.

164. Balbuena, 2004 N.Y. App. Div. LEXIS 15627 at *2.

165. Id. at *5 (Ellerin, J., dissenting).

166. Tyson Foods Inc. v. Guzman, 116 S.W.2d 233, 244 (Tex. Ct. App. 2003); Wudson Rosa v. United Rentals, Inc., No. 2004-232, 2005 N.H. LEXIS 35 (N.H. 2005) (allowing undocumented worker to sue for recovery of injuries while finding his immigration status admissible evidence).

167. See Chopra v. U.S. Professionals L.L.C., No. W2004-01189-COA-R3-CV, 2005 WL 28036 (Tenn. Ct. App. Feb. 2, 2005). Two state law cases predating Hoffman had also allowed unauthorized workers to sue for breach of contract, see Gates v. Rivers Constr. Co., 515 P. 2d 1020,1024 (Alaska 1973) or recover based on an unjust enrichment theory, see Nizamuddowlah v. Bengal Cabaret, Inc., 399 N.Y.S.2d 854, 857 (N.Y. Sup. Ct. 1977).

168. Chopra, 2005 WL 28036 at $* 3-4$.

169. See supra Part I. 
conditions and the lives of undocumented workers. For example, one of the overlooked aspects of post-IRCA life for the undocumented worker is the enforcement of sanctions against employers for the hiring of undocumented workers. ${ }^{170}$ Argentina, among other countries, focuses on the employer as the locus of the enforcement of sanctions against the hiring of undocumented workers, as will be shown in the next part of this article. ${ }^{171}$

Table 1. Summary of Applicability and Remedies Available to Undocumented Workers in the United States Post Hoffman Decision under Various Labor and Employment Laws.

\begin{tabular}{|c|c|c|}
\hline $\begin{array}{c}\text { Legal } \\
\text { Regime }\end{array}$ & Case(s) & Applicability/Remedy Available \\
\hline $\begin{array}{l}\text { National } \\
\text { Labor } \\
\text { Relations } \\
\text { Act (NLRA) }\end{array}$ & $\begin{array}{c}\text { Hoffman Plastic Compounds } \\
\text { v. NLRB, } 535 \text { U.S. } 137 \text { (2002) } \\
\text { In re Tuv Taam, } \\
\text { 340 NLRB No. } 86 \text { (2003) }\end{array}$ & $\begin{array}{l}\text { Only cease and desist order. No } \\
\text { backpay as remedy for unfair labor } \\
\text { practices. May include compensation } \\
\text { for work performed. }\end{array}$ \\
\hline $\begin{array}{l}\text { Fair Labor } \\
\text { Standards } \\
\text { Act } \\
\text { (FLSA) }\end{array}$ & $\begin{array}{c}\text { Singh v. Charanjit Jutla, } \\
214 \text { F. Supp. 2d. } 1056 \text { (N.D. Cal. 2002) } \\
\\
\text { Zeng Liu v. Donna Karan, } \\
\text { 207 F. Supp. 2d } 191 \text { (S.D.N.Y. 2002) }\end{array}$ & $\begin{array}{l}\text { Back wages for work actually } \\
\text { performed. Immigration status not } \\
\text { relevant nor discoverable. }\end{array}$ \\
\hline $\begin{array}{l}\text { Americans } \\
\text { with } \\
\text { Disabilities } \\
\text { Act (ADA) }\end{array}$ & $\begin{array}{l}\text { Lopez v. Superflex } \\
\text { (Unpublished opinion) }\end{array}$ & $\begin{array}{l}\text { An award of backpay is not a } \\
\text { prerequisite for punitive damages } \\
\text { under the ADA. Do not need to plead } \\
\text { lawful presence. Yet court in dicta } \\
\text { suggests that if issue came before it, it } \\
\text { would probably follow Hoffman. }\end{array}$ \\
\hline \multirow{3}{*}{$\begin{array}{l}\text { Title VII } \\
\text { (Anti Disc.) } \\
\text { and State } \\
\text { Anti Disc. } \\
\text { Statutes }\end{array}$} & $\begin{array}{l}\text { De La Rosa v. Northern Harvest Furniture, } \\
\text { 210 F.R.D. } 237 \text { (C.D. Ill. 2002) (Title VII) }\end{array}$ & $\begin{array}{l}\text { Undocumented workers are covered by } \\
\text { federal employment discrimination } \\
\text { statutes. }\end{array}$ \\
\hline & $\begin{array}{c}\text { Rivera v. NIBCO, } \\
\text { 364 F.3d } 1057 \text { (9th Cir. 2004) (Title V) }\end{array}$ & $\begin{array}{l}\text { Undocumented worker not forced to } \\
\text { disclose immigration status. }\end{array}$ \\
\hline & $\begin{array}{c}\text { Crespo v Evergo Corp., } \\
841 \text { A.2d } 471 \text { (N.J. Super. Ct. App. Div. } \\
\text { 2004) (NJ state law) } \\
\\
\text { Escobar v. Spartan, } \\
\text { 281 F. Supp. 2d 895 (S.D. Tex. 2003) } \\
\text { Morejon v. Hinge } \\
\text { (CA - unpublished opinion) }\end{array}$ & $\begin{array}{l}\text { Undocumented worker was not } \\
\text { allowed to recover economic damages } \\
\text { including backpay. } \\
\text { Unclean hands prevented recovery }\end{array}$ \\
\hline
\end{tabular}

170. See supra note 6 for data regarding the lax enforcement of employer sanctions for the hiring of undocumented workers.

171. See infra Part IV. 


\begin{tabular}{|c|c|c|}
\hline $\begin{array}{c}\text { Legal } \\
\text { Regime }\end{array}$ & Case(s) & Applicability/Remedy Available \\
\hline \multirow[t]{2}{*}{$\begin{array}{c}\text { Worker's } \\
\text { Comp. }\end{array}$} & $\begin{array}{l}\text { Reinforced Earth Co. v. Worker's Comp. } \\
\text { App. Bd. (Astudillo), 810 A.2d } 99 \\
\text { (Pa. 2002) }\end{array}$ & $\begin{array}{l}\text { Worker's Compensation benefits were } \\
\text { not precluded by undocumented status } \\
\text { Also CA, OK, MN, TN, OH, TN } \\
\text { (unpublished) }\end{array}$ \\
\hline & $\begin{array}{c}\text { Sanchez v. Eagle Alloy Inc., } \\
684 \text { N.W.2d } 342 \text { (Mich. 2004) } \\
\text { Mora v. DDP Contractors } \\
\text { 845 A.2d } 950 \text { (Pa. Commw. Ct. 2004) }\end{array}$ & $\begin{array}{l}\text { Cannot collect worker's compensation } \\
\text { benefits upon employer being notified } \\
\text { of undocumented status. No wage loss } \\
\text { benefits if undocumented. Also IN } \\
\text { (unpublished) }\end{array}$ \\
\hline \multirow[t]{2}{*}{$\begin{array}{c}\text { Tort } \\
\text { Recovery }\end{array}$} & $\begin{array}{l}\text { Madeira v. Affordable Housing Inc., } \\
\text { 315 F. Supp. 2d } 504 \text { (S.D.N.Y. 2004) } \\
\text { Tyson v. Guzman } \\
116 \text { S.W.3d } 233 \text { (Tex. App. 2003) }\end{array}$ & $\begin{array}{l}\text { Can collect compensatory damages for } \\
\text { personal injuries sustained during } \\
\text { course of work. } \\
\text { Tort recovery not precluded by } \\
\text { undocumented status }\end{array}$ \\
\hline & $\begin{array}{l}\text { Veliz v. Rental Service Corp., 313 F.Supp. } \\
\text { 2d } 1317 \text { (N.D. Fla. 2003) } \\
\\
\text { Sanango v. } 200 \text { E. } 16^{\text {th }} \text { Str. Hous. } \\
\text { (Unreported FL opinion) } \\
\text { Balbuena v. } 42^{\text {nd }} \text { Str. Dev. } \\
\text { (NY - unreported opinion) } \\
\text { Cano v. Mallory, } \\
760 \text { N.Y.S. } 2 \mathrm{~d} 816 \text { (N.Y. Sup. Ct. 2003) } \\
\text { Celi v. } 42^{\text {nd }} \text { Str. Dev. } \\
\text { (NY - unpublished opinion) }\end{array}$ & $\begin{array}{l}\text { Cannot recover for lost wages in a tort } \\
\text { lawsuit. } \\
\text { Can recover lost earnings from home } \\
\text { country. } \\
\text { Issue of undocumented status may be } \\
\text { presented to the jury with regard of } \\
\text { lost earnings }\end{array}$ \\
\hline
\end{tabular}




\section{CURRENT STATUS OF IMMIGRATION LAW POLICY IN ARGENTINA REGARDING UNDOCUMENTED WORKERS}

Argentina is a Latin American country with a very rich immigrant past ${ }^{172}$ and present. $^{173}$ Because Argentina is one of the main immigrant receiving countries in the Americas, it is worth analyzing and comparing its treatment of the undocumented worker with the United States's. Although Argentina boasts a large immigrant population, ${ }^{174}$ its undocumented population in comparison to the United States makes up a significantly smaller proportion of its immigrant population. ${ }^{175}$ Nevertheless, it is important to analyze the response of the Argentine legal system to undocumented workers, since that country has opened its doors to immigrants despite serious economic difficulties, and has not experienced the deep ambiguity or the hostile inconsistency with regard to these workers seen in the United States.

In recent times, the complexities of immigration law and policy, and their potential conflicts with worker rights and privileges, have taken a greater meaning following Argentina's entry into MERCOSUR, the Southern Cones' scheme of regional integration. ${ }^{176}$ Now, two different sources of law may affect

172. See Fernando Devoto, Historia De La Immigracion Argentina 294 (2003) (noting that the 1914 census showed the country to be $27.3 \%$ immigrant); see also, Lawrence M. Friedman, Erewhon: The Coming Global Legal Order, 37 STAN. J. INT'L L. 347 (2001) (describing Argentina as an "immigration"country that was always eager to recruit new citizens); CARL SOLDBERG, IMMIGRATION AND NATIONALISM 7 (1970) (discussing Argentine political view that "to govern is to populate," and the quickest method to do this is via immigration); see also Barbara Hines, An Overview of Argentine Immigration Law, 9 IND. INT'L \& COMP. L. REV. 395, 395 (1999) (discussing Argentine Constitution's provisions encouraging immigration to that country.").

173. See U.N. ReSEARCH INST. FOR SOC. DEV., ThE DYNAMICS OF ARgENTINE Migration vii (Alfredo Lattes \& Enrique Oteiza, eds., 1987) (discussing current pattern of migration in Argentina, which shows substantial influx of immigrants).

174. Current official figures indicate that the immigrant population in Argentina is comprised of a little under two million immigrants. See Instituto Nacional de Estadistica y Censo, Población total por lugar de nacimiento, según provincia, at http://www.indec. mecon.gov.ar/ (last visited Dec. 30, 2004).

175. The latest data from the International Labor Organization indicates that there are 800,000 undocumented immigrants in Argentina. En la Argentina: Hay 800 mil immigrantes ilegales, EL TRIBUNO (Salta, Argentina) May 21, 2004 available at $\mathrm{http}: / / \mathrm{www}$.eltribuno.com.ar/ 2004/nacionales/20040521_221524.php (last visited Mar. 15, 2005). Other estimates have found the undocumented population in Argentina to be in 50,000 to 2,500,000 range. See Hines supra note 172 at 398.

176. The Southern Cone of South American typically refers to the southernmost countries of South America: Argentina, Chile, and Uruguay. See Horacio Sabarots, Inmigrantes vs. "Ilegales": Estereotipos Desigualitarios en la Sociedad Argentina, at 2, available at http://www.ehu.es/CEIC/AMERICA/recursos/INMIGRANTES_VS.pdf(Oct. 1999) (last visited Mar. 15, 2005). For an excellent discussion of MERCOSUR, see Rafael A. Porrata-Doria, Jr., MERCOSUR: The Common Market of the Twenty First Century?, 32 GA. J. INT'L \& COMP. L. 1 (2004) (discussing MERCOSUR's founding ascendancy in the 1990s); see infra Section IV.B. (discussing MERCOSUR and its implications); see also JOHN WEEKS, CENTER FOR DeVelopment Policy and Research, Have Workers in Latin America Gained fRom 
undocumented workers in Argentina, depending on their country of origin and migration. Immigrants coming from a non-MERCOSUR country are subject to Argentine immigration law as well as any other treaty or bilateral agreement between the immigrant's country of origin and Argentina. ${ }^{177}$ However, if an immigrant is from a MERCOSUR participant or associate country, and migrates to another participating or associate country, he or she will be subject to the country's immigration laws as well as MERCOSUR - in a light most favorable to the immigrant- to effectuate MERCOSUR's final objective of the free circulation of persons among its signatory countries. ${ }^{178}$ Though possibly subject to more than one source of law, immigrant workers to Argentina can at the very least rest assured that neither scheme mandates the revocation of specific labor remedies should they become undocumented.

\section{A. Argentina's Immigration Law}

Argentina's current immigration law includes particular provisions designed to protect the immigrant worker legally residing there. Article 20 of the immigration law provides that the country will admit foreigners and classify them into one of three categories: permanent residents ("residentes permanentes"), temporary residents ("residentes temporarios"), or transient residents ("residentes transitorios."). ${ }^{179}$ Until the Argentine government processes all formal documents, it grants the foreigner applying for any of the above statuses a form of residency called precarious residency status ("residencia precaria") for a period of 180 days. ${ }^{180}$ This provisional residency affords foreigners various privileges, including the ability to work during that period. ${ }^{181}$ Obtaining this precarious residence is not a very complicated matter, and is usually completed with relative ease and without the long waits endured by immigrants wanting to enter the United States. For example, the number of immigrants moving to Argentina permanently in the years 1995-2002, is but a fraction of those seeking permanent residency in the United States in the year 2004. ${ }^{182}$

Liberalization and Regional InTEgration?, CDPR Discussion PaPER. 1199 (1999), available at http://www.soas.ac.uk/cdp rfiles/dp/DP11JW.PDF (discussing workers' rights and exercise of those rights as key to the equitable distribution of gains from liberalization and integration growth in Latin America).

177. See e.g. Law No. 25.889, May 17, 2004, B.O. 18/05/04 (Arg.) (bilateral Migration Agreement between Argentina and Peru).

178. See Law No. 25.871, Jan. 20, 2004, B.O. art. 28 (Arg.).

179. Id. at art. 20.

180. Id.

181. Id.

182. During the years $1995-2002$, census data shows that 89,388 foreigners settled permanently in Argentina for those years. INSTIUTO NACIONAL DE ESTADISTICA Y CENSOS, RADICACION DEFINITVA DE EXTRANJEROS POR AÑO DE OBTENCION DEL BENEFICIO SEGUN GRUPOS DE NAICONALIDADES 1995-2002, at http://www.indec.mecon.ar/ (last visited Mar. 25, 2005). In comparison, there were 662,029 immigrants admitted to the United States in the year 2004 alone. UNITED STATES DEPARTMENT OF HOMELAND SECURTY, CITIZENSHIP AND IMMIGRATION SERVICES, IMMIGRATION INFORMATION, IMMigration IN Fiscal Year 2004, at 
Foreign workers are covered by treaties or agreements entered into by the Republic of Argentina and the country's immigration law, whichever is more favorable for the migrant person. ${ }^{183}$ However, Article 53 explicitly prohibits foreigners residing "irregularly" in the country from working. ${ }^{184}$ In this context, the term "irregular" refers to those immigrants residing in Argentina without proper residency documentation.

Like immigration law and policy in the United States, Argentine immigration law prohibits employers from employing foreign workers residing "irregularly." "However, further provisions make clear that the application of this law will not exempt an employer from obligations emerging from labor legislation regarding foreigners, regardless of their immigration status. ${ }^{186}$ More importantly, the law states that immigration status will not affect the rights of foreign workers acquired through work already performed. ${ }^{187}$ Similar to U.S. policy as set forth in IRCA, the law in Argentina also imposes sanctions on those who employ or recruit foreign workers lacking the proper migration status to work. ${ }^{188}$ For every foreigner hired by an employer in violation of such provision, the law imposes a fine in the amount of fifty minimum salaries. ${ }^{189}$

Thus, in summary, one of Argentina's articulated goals regarding foreign workers is for the country to adopt all necessary measures that will effectively eliminate the employment of immigrants with "irregular" status (those without working or residency papers). ${ }^{190}$ In an effort to promote this purpose, Argentina's immigration law calls for the imposition of sanctions on employers, without diminishing the rights of immigrant workers in regard to their employment. ${ }^{191}$

Argentine case law confirms this view. In an early leading en banc appellate decision, the court of appeals in labor matters found that the fact that the employment contract with an undocumented worker is invalid should not be a bar for the judiciary to recognize the worker's right to obtain his labor law

http://uscis.gov/graphics/shared/aboutus/statistics/annual/fy94/722.htm (last visited Mar. 25, 2005).

183. Law No. 25.871 at art. 28.

184. Id. at art. 53 .

185. Id. at art. 55 .

186. Id. at art. 56.

187. Id.

188. Id. at art. 55. See also Law No. 20.744, May 13, 1976, B.O. art. 40, 42 (Arg.) (prohibition of illegal employment contracts directed at the employer and will not affect the right of the employee from receiving pay for work performed during the contract period or compensation after the contract ends.).

189. Id. at art. 59. The minimum salary in Argentina currently is 450 pesos per month for salaried employees and 2.25 pesos per hour for hourly workers. Decree No. 1194, Sept. 1, 2004, B.O. art. 1 (Arg.). The current exchange rate is approximately 3 pesos per U.S. Dollar; thus, the fine amounts under Argentine law for the hiring of undocumented workers would be 22,500 pesos or approximately $\$ 7500$ U.S. Dollars for salaried employees and 112.50 or $\$ 37.50$ U.S. Dollars per hour for hourly workers. Compare these fines with those recently assessed to the employers who hired undocumented workers in the United States, supra note 6.

190. Law No. 25.871, Jan. 20, 2004, B.O. art. 16 (Arg.).

191. Id. 
remedies. ${ }^{192}$ Subsequent cases have reaffirmed this holding and for example, stated that the employer cannot raise the defense of the void contract to an action by an employee ${ }^{193}$ and have even allowed an undocumented worker to recover compensation for being fired for refusing to perform certain tasks. ${ }^{194}$ Furthermore, an undocumented worker's right to salary for unlawful firing has been confirmed by a court even in the face of the employer's knowing act of hiring an undocumented Chilean worker. ${ }^{195}$ Finally, once an employer has received a fine for hiring undocumented workers, courts have refused to apply equitable principles or consider ability to pay as a factor to reduce the fine. ${ }^{196}$ Instead they require strict compliance with the enforcement of employer sanctions for having hired undocumented workers in Argentina. ${ }^{197}$

\section{B. Immigrant Workers and the Law of MERCOSUR}

The existence of MERCOSUR further complicates the situation regarding immigrant workers in Latin America and particularly in Argentina. MERCOSUR is a regional integration organization in which Argentina, Brazil, Uruguay, and Paraguay are member countries, and Chile and Bolivia are associate countries. ${ }^{198}$ Created by the Treaty of Asunción in 1994, MERCOSUR's ultimate goal is to create a common market for member countries throughout the southern cone region. ${ }^{199}$ In addition to the removal of trade restrictions among member countries and the imposition of a common tariff to non-member countries, a common market includes the free movement of production factors such as labor, capital, and resources. ${ }^{200}$

In 2002, all MERCOSUR member and associate countries signed an agreement addressing and establishing residency norms for immigrant workers. ${ }^{201}$ The agreement establishes a uniform method for granting temporary resident status of up to two years for immigrants of member banc).

192. "Nauroth y Echegaray," CNTrab. 193 [LEXIS Argentina No. 60000831] (1973) (en

193. "Portillo, López," CNTrab. No. 6 [LEXIS Argentina No. 13/5401] (1987).

194. “De Aguilar, Marinete," CNTrab. No. 10 [LEXIS Argentina No. 30000530] (1999).

195. "Lezcano, Angelica," CNTrab. No. 3 [1994 J.A. 387].

196. "Coman, Ana R. v. Dir. Nac. Migraciones," CNFed. No. 4 [May 21, 2002].

197. Id.

198. See Argentina-Brazil-Paraguay-Uruguay: Treaty Establishing a Common Market, Mar. 26, 1991, 30 I.L.M. 1041 (entered into force Dec. 31, 1994); see also Porrata-Doria, supra note 176 , at 1 .

199. Id.

200. Iris Mabel Laredo, The Regional Integration as an Alternative in the New World Order, in INTEGRACIÓN REgIONAL AMERICANA COMPARADA (John S. Shultz ed., 1995).

201. Law No. 25.903, July 13, 2004, B.O., art. 1 (Arg.) (ratifying Agreement Regarding Residency for Nationals of MERCOSUR Party States). It should be noted that this Agreement was proposed as an alternative to a general amnesty program throughout the MERCOSUR. See Acuerdo Historico en Brasil, LA FRAGUA, (Nov. 12, 2002) (transcript interview with Argentina's Immigration Minister) (on file with author). 
countries. ${ }^{202}$ As was the case in Argentina's immigration law, most of the provisions included in the agreement aim to protect the rights of those immigrants of "regular" status. ${ }^{203}$ For example, according to the agreement, all participating countries must embrace a unified effort to deter the employment of "illegal" immigrants in each other's territories. ${ }^{204}$ More specifically, parties that employ workers in "illegal" conditions will face the imposition of sanctions. Importantly, however, MERCOSUR's provisions also guarantee that the repercussions of such measures will not affect the rights of immigrant workers as a consequence of work already performed. ${ }^{205}$ It is in these particular provisions that the disparity between the United States and Latin America becomes apparent.

Thus, although immigration laws in Argentina and the MERCOSUR agreement may be similar to the policy of the United States, those legislative provisions provide two fundamental distinctions that make an enormous difference for the rights of undocumented workers. First, the process to obtain residency status throughout Latin America is much more feasible for immigrants wanting to migrate. Second, the legislative provisions related to undocumented workers in Argentina provide a caveat that though courts may sanction employers for hiring "irregular" immigrants, the worker will retain those rights acquired as a result of the work already performed. These factors, when compared with the United States' approach, illustrate an important distinction in immigration policy and further magnify the implications of Hoffman to undocumented workers. When analyzed in conjunction, it is fair to say that "irregular" workers in Argentina enjoy certain established rights that undocumented workers in the United States do not enjoy, post-Hoffman, in a consistent manner.

\section{CONCLUSION}

At least five solutions to the current hostile inconsistency in the lives of undocumented workers in the United States exist. Three come in the form of proposals in the domestic realm; the other two resort to international law remedies. One commentator has proposed the enactment of a federal statute that would "specifically provide[] undocumented workers with the right to bring claims under federal statutes aimed at ensuring fair practices and equal protection in employment." 206 This proposed statute should include an available remedy in the event that the traditional labor statute's remedy

202. Id. at art. 5 .

203. See, e.g., id. at art.9 (granting equal civil rights to those who have obtained residency according to the terms of the Agreement).

204. Id. at art.10.

205. Id. at art. $10(\mathrm{~b})$.

206. Elizabeth M. Dunne, The Embarrassing Secret of Immigration Policy: Understanding Why Congress Should Enact an Enforcement Statute for Undocumented Workers, 49 EMORY L.J. 623, 672 (2000). 
conflicts with immigration policy. This proposal would appear to be an excellent solution to the IRCA-induced inability of many courts to effectuate labor law policy, yet in the current climate, it is not a feasible solution. Following the September 11, 2001, tragedy, there does not appear to be much support at the federal legislative level for any seemingly pro-immigrant legislation. Other federal proposals that have been called for include the enactment of sanctions against the employers in the amount of wages saved by hiring undocumented workers, ${ }^{207}$ or for limited amnesty for undocumented workers who have good faith labor law claims. ${ }^{208}$ These also do not appear to be feasible at this time, for the post-9/11 anti-immigrant reasoning stated above.

A second domestic solution suggests a call to state legislatures and courts to play an even more active role to protect the labor and employment law rights of the undocumented workers. The example of Virginia in the worker's compensation context ${ }^{209}$ should serve as a harbinger for future expansion of protection of the undocumented. Also, in 2002, shortly after the Hoffman decision, the state of California passed SB 1818, commonly called the "Hoffman fix." 210 The enactment of Chapter 1071 amends California's Labor Code, ${ }^{211}$ Government Code, ${ }^{212}$ Health and Safety Code, ${ }^{213}$ and Civil Code, ${ }^{214}$ and makes. immigration status irrelevant for the enforcement of state labor, employment, civil rights and employee housing laws. The amendment also prohibits discovery into such status absent a showing of clear and convincing evidence. ${ }^{215}$ This is yet another example of the power of the states to overcome the federal immigration policy's untoward reach, based on the Supreme Court's interpretation of the IRCA's policy in Hoffman.

The last domestic solution is found in two recently introduced federal bills that propose to restore and reaffirm the legal rights and remedies of undocumented workers under civil rights statutes. More specifically, in order to provide protection to undocumented workers, H.R. 3809, the Fairness and Individual Rights Necessary to Ensure a Stronger Society (FAIRNESS) Act, would amend the language of the Immigration and Nationality Act (INA). ${ }^{216}$ The bill proposes to amend section $274 \mathrm{~A}(\mathrm{~h})$ of the INA by including language

207. See Shahid Haque, Note, Beyond Hoffman Plastic: Reforming National Labor Relations Policy to Conform to the Immigration Reform and Control Act, 79 CHI.-KENT L. REV. 1357 (2004).

208. See Sara Bollerup, America's Scapegoats: The Undocumented Worker and Hoffman Plastic Compounds Inc. v. National Labor Relations Board, 38 NEW ENG. L. REV. 1009 (2004).

209. See supra note 137 and the accompanying text.

210. S.B.1818, 2001-02 Sess. (Cal. 2002) (codified at CAL. Civ. Code 3339 (West. Supp. 2003)).

211. CAL. LAB. CODE $\$ 1171.5$ (Deering 2004).

212. CAL. Gov't CODE $\$ 7285$ (Deering 2004).

213. Cal. Health AND Safety CODE $\S 24000$ (Deering 2004).

214. CAL. CIV. CODE $\S 3339$ (Deering 2004).

215. S.B.1818, 2001-02 Sess.

216. Fairness and Individual Rights Necessary to Ensure a Stronger Society: Civil Rights Act of 2004, H.R. 3809, 108th Cong. $\$ 702$ (2004). 
that would not deny backpay remedies to a present or former employee for either the employer's or employee's failure to comply with the section's particular requirements or federal law violation related to the established employee verification system. ${ }^{217}$ In its findings, the bill announces numerous concerns resulting from the court's decision in Hoffman. ${ }^{218}$ In particular, the bill distinctly notes that the majority in Hoffman made clear that "any 'perceived deficiency in the NLRA's existing remedial arsenal'. must be 'addressed by congressional action." "219 Furthermore, S. 2381/HR 4262, the Safe, Orderly, Legal Visas and Enforcement (SOLVE) Act, sponsored by Senators Kennedy, Clinton and Feingold, and by Representative Gutierrez and over forty co-sponsors in the House, added to its other immigration proposals the restoration of labor rights denied in Hoffman. ${ }^{220}$ Although these bills failed to be enacted in the $108^{\text {th }}$ Congress and have not been reintroduced, the mere fact that they were proposed is telling of the viability to legislatively address the restoration of the labor protections of undocumented workers that the Supreme Court denied in Hoffman.

Finally, there are two international law approaches that could address the effects of Hoffman. The first is a human rights approach, ${ }^{221}$ which may force the United States to view the dilemma of undocumented workers from a wider perspective than merely its domestic immigration policy by taking into account the Universal Declaration of Human Rights and other international human rights norms. The feasibility of such a proposal is unclear in this era in which U. S. courts have just begun to apply customary international law in their decisionmaking. ${ }^{222}$ If this era continues, a proposal of this kind may succeed in the future.

Another international law approach consists of the invocation of international organizations' oversight functions. In fact, the AFL-CIO filed a complaint with the International Labor Organization (ILO) in protest of Hoffman and its limitation of remedies to undocumented workers in the United States, claiming the decision contravened international treaties on worker's

217. Id.

218. Id. \& 701 .

219. Id.

220. See Safe, Orderly, Legal Visas and Enforcement (SOLVE) Act of 2004, S. 2381, 108th Cong. § 321(2004); see also, Safe, Orderly, Legal Visas and Enforcement (SOLVE) Act of 2004, H.R. 4262, 108th Cong. \$ 321(2004).

221. Neil A. Friedman, A Human Rights Approach to the Labor Rights of Undocumented Workers, 74 CAL. L. REV. 1715 (1986).

222. See Roper v. Simmons, 125 S. Ct. 1183,1199 (2005) (citing U.N. Convention on the Rights of the Child and other international law covenants to forbid execution of juveniles under the Eight Amendment.); but see Beharry v. Reno, 183 F. Supp. 2d 584,595-601 (E.D.N.Y. 2002), rev'd, 329 F.3d 51, 64 (2d Cir. 2003) (reversing on other grounds lower court's decision that deportable noncitizen should be afforded hearing regarding the right of U.S. citizen child to be raised with two parents as required by U.N. Convention on the Rights of the Child, the Universal Declaration of Human Rights and other customary international law.). 
rights. ${ }^{223}$ In response, the ILO concluded that the available remedies left to the NLRB were inadequate to ensure the effective protection against anti-union discrimination. ${ }^{224}$ The ILO did not offer a proposed remedy or sanction, but it asserted that executive and congressional action must address the deficiency. ${ }^{225}$ The Committee's report concludes with a recommendation inviting the government to explore all possible solutions, including legislative amendments, in order to ensure the protection of all workers against anti-union discrimination in the wake of the Hoffman decision. ${ }^{226}$

The oversight of the Inter-American Human Rights system is another action that was undertaken by the Government of Mexico by filing with the Inter-American Court of Human rights a complaint on behalf of its citizen workers in the United States. The Court issued its comprehensive advisory opinion in 2003, where it unequivocally declared that workers should be treated equally regardless of immigration status. ${ }^{227}$

In conclusion, the place of the undocumented worker in the United States' legal realm has moved from deep ambivalence to hostile inconsistency. Other immigrant-receiving countries, as shown by Argentina's as well as MERCOSUR's legal regimes, demonstrate that prohibitions on hiring undocumented workers need not eliminate those workers' labor law protections. It may serve the United States well to look to the south for some valuable lessons in how to treat those vulnerable workers in an effort to deter unauthorized immigration. Even as signs emerge hinting of remedies for undocumented workers in some areas of labor law protection, the sheer denial of some rights is certainly cause for concern.

In the three years following Hoffman, the decision has been used by some to send a message to undocumented workers to be docile and not complain about their working conditions or else. ${ }^{228}$ The message of "[k]now your place, do the work, stay in the shadows, accept what your betters give you and never think of organizing to challenge the structure which holds you in chains" is still

223. See Reports of the ILO Committee of Freedom of Association No. 329, 331 (LXXXIV, 2003, Series B, No. 2) re: Case No. 2227 (United States) October 18, 2002, complaint by the AFL-CIO.

224. See Reports of the ILO Committee of Freedom of Association No. 332 (LXXXVI, 2003, Series B, No. 3) May 9, 2003.

225. Id. It should be noted that with regard to its enforcement mechanisms, the ILO's shortfall has been "its lack of bite." See Phillip Seckman, Invigorating Enforcement Mechanisms of the International Labor Organization in Pursuit of U.S. Labor Objectives, 32 DENV. J. INT'L L. \& POL'Y 675, 697 (2004).

226. See Reports of the ILO Committee of Freedom of Association No. 332 supra note 224.

227. See Sarah Paoletti, Human Rights for all Workers: the Emergence of Protections for Unauthorized Workers in the Inter-American Human Rights System, 12 HUM. RTS. BRIEF 5 (2004)(discussing Inter-American Court of Human Rights advisory opinion and its critical guidance with regard to migrant workers.).

228. David Bacon, Supreme Court v. Unions, ThE NATION, May 2, 2002, available at http://www.thenation.com/doc.mhtml?i=20020520\&s=bacon) (last visited Dec. 30, 2004). 
alive and well, albeit with some protections granted erratically to the undocumented worker in our midst. Simply put, these actions deny the undocumented workers in our midst of the most basic of their attributes, their personhood. The denial of the undocumented workers' personhood because they lack U.S. citizenship should not be part of their existence in our democratic state as it is not consistent the ideals of freedom and equality that founded this nation. 
